\title{
White clover seed production with irrigation
}

\author{
J. K. LAY \\ Irwell
}

\begin{abstract}
Irrigation has removed much of the risk associated with white clover seed production in an area of poorly distributed annual rainfall of $580 \mathrm{~mm}$. Machine-dressed seed yields range between 540 and $900 \mathrm{~kg} / \mathrm{ha}$. The importance of minimizing harvesting losses is emphasized.
\end{abstract}

Key words: Trifolium repens, seed produr:ion, irrigation.

\section{INTRODUCTION}

In partnership with my wife, I farm 91 ha of good cropping land. The farm is exceedingly flat and the removal of internal permanent fences (to accommodate two side-roll irrigation systems) and their substitution in the nonirrigation season by electric fences are features of our farm. A very poorly distributed $580 \mathrm{~mm}$ of rain usually leaves us with an overabundance of water in the winter and a deficit in the spring/early summer season.

The successful production of 'Grasslands Huia' (Trifolium repens L.) white clover seed has, for the past 6 years, determined my success or failure as an arable farmer. The installation of the sprinkler irrigation system in 1974 has meant the removal of much of the risk associated with the growing of this crop. As a result I now produce clover seed off half my farm and expect machine-dressed yields ranging between 540 and $900 \mathrm{~kg} / \mathrm{ha}$. Seed production from this proportion of my farm under dryland farming conditions would not have made economic sense.

With only a few exceptions, I attempt to manage my crop as closely as possible to the recommendations propounded by Peter Cliford. Peter's poem on clover production, published and released at last year's Lincoln Col- lege, Mixed Cropping Farm Field Day, is pinned to my office wall. By following his recommendations, I consider that I am using my soil to produce clover to its maximum potential.

In order of importance, however, I consider that soil type has the greatest influence on yield, followed by weather and then management. Some farmers are said to be better than others in producing clover seed, but usually a glance at a soil map will reveal the reason. I have two soil types on my farm: "Temuka Clay Loam", a heavy, stiff, fertile soil with impeded drainage, and "Wakanui Sandy Loam on Clay Loam", a more fertile, freer-draining and loamier soil. Unfortunately, my farm is made up of $90 \%$ of the former and $10 \%$ of the latter. I mention this soil difference to substantiate my previous comments on soil type, in that without irrigation or drainage, and with only minimal management, the Wakanui soil will consistently yield $900 \mathrm{~kg} / \mathrm{ha}$ of machine-dressed seed. The Temuka soils can -achieve the same results, but normally require irrigation, drainage and intensive management

\section{ROTATIONS}

My most profitable rotation used to be simply wheat and white clover, but because of a serious inherent weed problem I have in more recent years changed to wheat-white clover-greenfeed/barley-white clover. This rotation has allowed me to maintain my clover area while providing for two cultivation attacks on the main weed scourge - couch, Agropyron repens L. (Beauv.) - in the greenfeed/barley year. I am hopeful that the advent of the chemical glyphosate will allow me to return to the more profitable wheat-white clover rotation. Both the barley and the wheat stubble are removed from the farm. 


\section{ESTABLISHMENT}

I usually undersow basic clover seed at a rate of $2.25 \mathrm{~kg} / \mathrm{ha}$ at the time of drilling the cover crop. This seed is broadcast through a rape seed box on to the ground in front of the drill. I intend to drill in $30 \mathrm{~cm}$ rows in the future. My present rotation means a division of establishment between autumn and spring, but so far I have been unable to detect a seasonal difference. The application of water in the spring to the cover crop usually ensures a good strike.

I will accept plant populations as low as $4 / \mathrm{m}^{2}$ if evenly spaced, but prefer 6 to 8 healthy plants $/ \mathrm{m}^{2}$. My final decision whether to accept or reject a crop is not made until late September in the year prior to harvest. If it has been necessary, because of an establishment failure, to make up my clover area, I have no hesitation in keeping a previous crop for a second harvest year. On many occasions these secondyear crops have outyielded their first-year counterparts.

I first became interested in keeping secondyear clover crops about 12 years ago when I observed a revitalization of the old clover stand following a period of top working, prior to wheat. I pursued this development and experimented with small areas which increased in size each year as it became clear that the method worked.

A farm adviser became interested in the operation but suggested that it was unnecessary to thin the clover as I was doing with my two light grubbings. He maintained that in the second year the parent plant emitted a hormone which suppressed flowering throughout the plant's stolon reach. He suggested that by using a set of heavily weighted discs, devoid of cut and pulled in two directions so as to cross each other, I would cut the stolon, isolate the parent plants, and create a series of new plants for the new season's crop. I still do this and, until it is proved to be unnecessary, I will continue to do it.

\section{FERTILIZERS}

Fertilizer is applied in accordance with MAF soil tests. If required. I prefer to apply superphosphate in the autumn because 1 find that spring applications tend to promote vegetative growth at the expense of flowering. If a nitrogen deficiency is identified, I apply sulphate of ammonia to clover in the spring.

\section{WINTER MANAGEMENT AND LIVESTOCK}

My clover crop is virtually ignored, following the removal of the cover crop at harvest time, until late September. Despite rain, wind, hail, flood or snow, the clover plant seems to have little trouble surviving. For a number of years I grew white clover as a specialist crop, and sheep were run at about 5 ewes/ha to keep the crop under control. Peter Clifford's poem suggests that you cannot graze clover and produce maximum seed yields, and in the main I agree with this. After the middle of October, livestock are absolutely forbidden on my clover, but prior to this their presence does not concern me.

In more recent times I have been direct drilling into it greenfeed wheat at $65 \mathrm{~kg} / \mathrm{ha}$ mixed with Italian ryegrass, 'Grasslands Paroa' (Lolium multiflorum Lam.), at $10 \mathrm{~kg} / \mathrm{ha}$, and the stocking rate has increased to 15 ewes/ha. This greenfeed is fed off, using electric fences to provide a daily ration calculated to a feedbudgeting formula. The sheep are confined to this daily area and arc not allowed to backgraze. During wet weather the daily area can become quitc pugged, but because it is grazed only twice during the winter there is plenty of time for recovery.

If I thought that the use of the greenfeed was reducing my clover yield, I would stop the procedure. A loss of a mere $90 \mathrm{~kg} / \mathrm{ha}$ of machine-dressed clover seed would represent a loss far exceeding any profit that I could hope to make from livestock off the same hectare. My experience to date has shown that the clover recovers rapidly from this intensive but brief grazing, and so at this stage I am hopeful of having my clover and eating it too.

\section{WEED AND PEST CONTROL}

$\mathrm{J}$ have already mentioned that couch is my major weed problem. My other serious weeds include wild oat (Avena Jatua L.), dandelion (Taraxacum officinale), wirewced (Polygonum aviculare agg.), suckling clover (Trifolium dubium Sibth.), Yorkshire fog (Holcus lanatus 
L.), scentless chamomile (Matricaria inodoru L.) and Phalaris minor Retz. Of course there are many other minor weeds and an assortment of thistles, all of which are assisted in their establishment by irrigation. Depending on the problem, I use carbetamide or paraquat for grass control. Carbetamide has other advantages as well, but in more recent times I have favoured paraquat at 1.4 to $2.1 \mathrm{I} / \mathrm{ha}$, not only because of its lower cost but also because it allows me to use my greenfeed for a longer period of time. J also suspect a slight suppression of the clover plant following the use of carbetamide. Most farmers are familiar with these chemicals and use them well. Pests such as blue-green aphid (Acyrfhosiphon kondoi Shinji) or case-bearer moth (Cleophora spp.) are treated with bromophos. I have also occasionally treated clover stands for slugs and springtails.

The many new chemicals with their variety of brand names and their varying potential to kill broadleaf weeds tend to confuse me. I rely very heavily on all the independent advice I can get in matters pertaining to their control. If the land is suitably firm in the August period, and if there is a series of sufficiently hard frosts, I am prepared to use, because of its ability to kill a broader spectrum of weeds including suckling clover, 2, 4-D ester at 4.5 $1 /$ ha. If the required conditions do not prevail, the results can be frightening.

Failing the use of the 2, 4-D ester, I am left with virtually one choice, and this of course is MCPB at about $41 / \mathrm{ha}$. I was interested to meet a farmer who had recently used the chemical glyphosate at very low rates (1.5 1/ha) for weed control and as a desiccant in his clover crop. He claimed that talk of smaller and lighter seed from the crop was unsubstantiated provided the chemical was applied before mid-September, and that so successful was his crop that he intends to try it again. I have since heard of glyphosate being used to assist with small seed production in the U.S.A. and it is my intention to try a boom width on one paddock this year.

\section{IRRIGATION}

I always try to keep the irrigation of white clover to a minimum. Following the application of paraquat, I feel safe in applying up to 50 $\mathrm{mm}$ of water, but after this application the situation becomes more difficult. I find that it is essential to maintain a moisture balance sufficient for seed production but insufficient for the production of vegetative growth. As I am on heavy land, rainfall following irrigation can upset this balance. For best results I try to keep the clover plant in a situation bordering on moisture stress, which at the moment is determined by eye appraisal and experience: but this year I am experimenting in monitoring moisture requirements using a series of strategically placed tensiometers.

I have no doubt that the optimum way to irrigate clover on my land is little and often. I do try to achieve this optimum with my side. roll irrigation system, but despite its ease of movement it involves me in many shifts, and demands of me extreme dedication to the task. Compromise is often necessary and this means that I am not always applying water to best effect.

To improve this situation in the future, 1 will be considering two alternative modifications to my side-roll. One consideration will be the travelling side-roll developed by the New Zealand Agricultural Engineering Institute at Lincoln, and the second is the addition of trailing sprinklers to the line, allowing me to achieve two irrigation sets for the one shift. Both of these systems would allow me to irrigate at low application rates $(3.5 \mathrm{~mm} / \mathrm{h})$, which also allow for more effective irrigation.

\section{HARVESTING}

I often wonder how much clover seed we lose at harvest time with our present equipment. I am sure that, despite our closest attention to detail, we rarely reap the full potential of the crop. I suspect that these losses could exceed all the others on which we spend much time and money trying to combat. J would like to see our agricultural engineers apply themselves to the improvement of equipment for harvesting clover.

My harvest involves the use of paraquat as a desiccant some four or five days before mowing and harvesting. These two operations are carried out with the Lespedeza mower, which is never allowed to precede the header by more than four or five rounds of the pad- 
dock. This reduces the possibility of windblow and makes threshing and separating reasonably straightforward. In earlier days I would close the header up as tight as a drum and travel at a snail's pace. Now I open the header up a little and travel at a good fast walking speed. The clover is harvested in bulk but is bagged off my scalper. I am querying the economics of scalping and in future may dispatch clover in bulk from the header directly to the seed merchant.

\section{CONCLUSION}

You will have noticed that I have not mentioned bees. Their role is obvious and, like any other grower, I encourage the beekeeper to place as many hives as possible on my property. I consider a hive to every 3 ha is sufficient.

Finally, may I say that I enjoy the challenge of growing and marketing clover. It is a crop with which you compete with everyone, including your neighbour. 